\title{
First Digit Lucas, Fibonacci and Benford Number in Financial Statement
}

\author{
Teguh, Sugiarto ${ }^{1,}$. Sandi, Noorzaman ${ }^{2,}$. Ludiro, Madu ${ }^{3,}$. Ahmad, Subagyo ${ }^{4}$.A.M.Amiri ${ }^{5,}$ \\ 1) Doctoral student Brawijaya University, \\ Departemen Accounting Universitas Budi Luhur \\ Jl. Ciledug Raya, Petukangan Utara, Pesanggrahan, Jak- Sel, \\ DKI Jakarta, Indonesia \\ 2 \& 4) Departemen Management at GICI Business School, \\ Jl. Margonda Raya No. 224, Kota Depok, Jawa Barat. Indonesia \\ Telp. 021-7760806 Faks. 021-7760807 \\ 3) Lecture at UPN Veteran, \\ Departemen Internasional Relation. \\ Universitas Pembangunan 'Nasional' Veteran, \\ Yogyakarta, Indonesia \\ 4) 2614 Dwight Way, Berkeley, CA 94720 \\ UC Berkeley, Safe Transportation, \\ Research \& Education Center, USA \\ ${ }^{1}$ teguh_cpconsulting@yahoo.com, ${ }^{4}$ bgy2000@yahoo.com, ludiro@gmail.com³ ${ }^{3}$, s_noorzaman @yahoo.com², amiri@berkeley.edu
}

\begin{abstract}
This study aims to explore if there is fraud in the company's financial report distribution using the number first digit Lucas, Fibonacci and Ben ford. In this study, the author uses a number model contained in the first digit of the model Lucas, Fibonacci and Ben ford, to make a distinction between implementation by using the scale above and below $5 \%$, the different rate of occurrence to the digit number contained on Lucas, Fibonacci and Benford. If there is a significant difference above and below $5 \%$, then the process of follow-up and detection of occurrence of fraud against the financial statements can be made. From research that has been done can be concluded that the number of frequency levels contained in the financial statements of PT Bank BRI Tbk in a year in the same conscientious results for model Lucas, Fibonacci and Benford.
\end{abstract}

Keywords-Lucas; Fibonacci; Benford; First digit; Financial reporting fraud

\section{INTRODUCTION}

He publication of a study performed by Nigrini (1992, 1996, 1999)[1]-[3] explains how the existence of a fairly strong influence in benford's law on the application of data analysis is performed. In a study of the use of accounting data and, Nigrini conducted a study on financial transactions in tax payments made by the company Nigrini concluded that the average taxpayer in the United States is more likely to commit fraud in the field of taxation, in the sense that they prefer to report their income tax as low as possible, so that the taxes will be paid later. In his study Nigrini explain how the policies that should be taken by the taxpayer, where by doing the understatements, thus can reduce the amount of tax to be paid significantly. In a similar study by Quick and Wolz (2005) [4] and Nigrini (1996 \& 2000) [2] [12] in economic and taxation data in Germany, USA and Switzerland. It needs to be underlined by the author in the line, later we can see how the model from analysis of benford's law with model numbers that once given, can explain all phenomena number figures in the financial statements of the company, help scale the upper limit and lower limit are certainly in use by the author, benford's law makes it increasingly became firmly according to the author. Anomalies of the case studies given by the author in the form of the financial statements of the company, could later be able to add science vocabulary analysis at the level of cheating in viewing numbers learn by use of benford's law..

\section{LITERATURE REVIEW}

In the Carslaw (1988) [13], McConville (1995) [14], Skousen, Guan and Wetzel (2004) [15], Nigrini (2005) [16], Quick, R and Wolz, M (2005) [4], Blasi (2010) [17], Bowen (2010) [18], Gadawaski (2010) [19], Simmons, (1995) [20], says about how fraud and making mistakes in financial statements can occur, or on purpose. Because the thing that is in conflict with the law are doing this for real, so that in the end can lead to financial benefits unilaterally. If we examine it literally, actually this fraud there are several categories of explanation, first fraud associated with bribery, fraud relating to both corruption and the last discussed by the author at this time i.e. fraud related to percentage. In terms of percentage, then the author uses analysis tools as used by the writer above, but in terms of the use of different case with the researchers. In the event of fraud happens as mentioned by the author before, then any consequences for some the sustainability of the results of research, as well as the possibility of effects can be detrimental to users information on the company or its management staff, the lenders and the existing capital market participants and need information on it. These authors view of the model anomaly Friday Fibonacci and lucas numbers, benford. Malcolm W.B.(1998) [21], Berber,et,al (2008) [22]. 
TABLE I COMPARISON FIRST DIGIT MODEL NUMBER LUCAS, FIBONACCI, BENFORD DISTRIBUTION

\begin{tabular}{|c|c|c|c|c|c|c|c|c|c|}
\hline \multicolumn{7}{|c|}{ FIRST DIGIT NUMBER MODEL } \\
\hline $\mathbf{1}$ & $\mathbf{2}$ & $\mathbf{3}$ & $\mathbf{4}$ & $\mathbf{5}$ & $\mathbf{6}$ & $\mathbf{7}$ & $\mathbf{8}$ & $\mathbf{9}$ & Model \\
\hline $30.10 \%$ & $17.60 \%$ & $12.55 \%$ & $9.65 \%$ & $7.95 \%$ & $6.65 \%$ & $5.85 \%$ & $5.10 \%$ & $4.50 \%$ & Lucas \\
\hline $30.05 \%$ & $17.65 \%$ & $12.50 \%$ & $9.65 \%$ & $7.95 \%$ & $6.65 \%$ & $5.75 \%$ & $5.20 \%$ & $4.60 \%$ & Fibonacci \\
\hline $31.103 \%$ & $17.609 \%$ & $12.494 \%$ & $9.691 \%$ & $7.918 \%$ & $6.695 \%$ & $6.099 \%$ & $4.815 \%$ & $4.576 \%$ & Benford \\
\hline
\end{tabular}

Sources: J. Wodarski, (1971). Fibonacci and lucas number tend to obey benfords law,"The fibonacci quarterly, Vol.9, No.1, pp.87-88 [23], B.J.Flehinger,(1966)”On the probability that a random integers has initial digit A,'Amer, Math, Monthly. Vol.73, pp. 1056-1061[24].

\section{RESEARCH METHODS}

\section{A. Data and time of research}

In this study Authors using financial statement (Balance sheet \& Profit and loss) data of PT BRI Tbk listed on the Indonesia Stock Exchange started quarter March-Dec for the year 2010-2015. The author conducting this study in July-Sept 2016.

\section{B. Analysis data technique}

In this study the author uses techniques of data analysis the first digit of the model Lucas, Fibonacci and Benford. The third model analysis tools from the first number digits, will see the difference in the results obtained, but the author retains the upper limit and lower limit of 5\% of the final analysis as a tool in determining whether a company's financial statements in carefully non-food and non-food material in the financial statements over the impact of cheating.

\section{Result and discussion}

With this background, the author makes the financial reports of a company as an example to see how the results of the use of the same formula, however in a different place. Armed with 3 model analysis that has been in use as the guidelines seek a conclusion about the digit number found on the financial reports of companies that comprise the model Fibonaci and Lucas, Benford. The writer is intentionally not used many examples of companies, because the want to get results in maximum deem by using samples of one company only. Here you can see how the results of the analysis of the rate of occurrence of numbers of model Lucas, Fibonacci and Benford.
TABLE II RESULT ANALYSIS LUCAS NUMBER PT BANK BRI TBK FOR THE YEAR 2010-2015

\begin{tabular}{|c|r|c|c|c|c|c|}
\hline No. & $\begin{array}{r}\mathbf{2 0 1 5} \\
\text { Diff }\end{array}$ & $\begin{array}{c}\mathbf{2 0 1 4} \\
\text { Diff }\end{array}$ & $\begin{array}{c}\mathbf{2 0 1 3} \\
\text { Diff }\end{array}$ & $\begin{array}{c}\mathbf{2 0 1 2} \\
\text { Diff }\end{array}$ & $\begin{array}{c}\mathbf{2 0 1 1} \\
\text { Diff }\end{array}$ & $\begin{array}{c}\mathbf{2 0 1 0} \\
\text { Diff }\end{array}$ \\
\hline 1 & $0.58 \%$ & $2.92 \%$ & $-2.58 \%$ & $-1.40 \%$ & $-1.67 \%$ & $-1.67 \%$ \\
\hline 2 & $0.46 \%$ & $1.27 \%$ & $-4.76 \%$ & $-4.64 \%$ & $1.03 \%$ & $1.03 \%$ \\
\hline 3 & $5.88 \%$ & $-5.95 \%$ & $-3.38 \%$ & $-4.22 \%$ & $1.18 \%$ & $1.18 \%$ \\
\hline 4 & $2.98 \%$ & $-1.16 \%$ & $-1.39 \%$ & $6.09 \%$ & $4.08 \%$ & $4.08 \%$ \\
\hline 5 & $1.57 \%$ & $0.54 \%$ & $10.40 \%$ & $5.94 \%$ & $-1.09 \%$ & $-1.09 \%$ \\
\hline 6 & $5.73 \%$ & $1.84 \%$ & $4.36 \%$ & $0.76 \%$ & $-3.71 \%$ & $-3.71 \%$ \\
\hline 7 & $0.82 \%$ & $-1.13 \%$ & $1.49 \%$ & $0.63 \%$ & $1.01 \%$ & $1.01 \%$ \\
\hline 8 & $3.47 \%$ & $0.56 \%$ & $-3.27 \%$ & $0.46 \%$ & $0.78 \%$ & $0.78 \%$ \\
\hline 9 & $1.64 \%$ & $1.16 \%$ & $-0.83 \%$ & $-3.57 \%$ & $-1.56 \%$ & $-1.56 \%$ \\
\hline
\end{tabular}

Sources: Proceed by author

TABLE III RESULT ANALYSIS FIBONACCI NUMBER PT BANK BRI TBK FOR THE YEAR 2010-2015

\begin{tabular}{|c|c|c|c|c|c|c|}
\hline No. & $\begin{array}{c}\mathbf{2 0 1 5} \\
\text { Diff }\end{array}$ & $\begin{array}{c}\mathbf{2 0 1 4} \\
\text { Diff }\end{array}$ & $\begin{array}{c}\mathbf{2 0 1 3} \\
\text { Diff }\end{array}$ & $\begin{array}{c}\mathbf{2 0 1 2} \\
\text { Diff }\end{array}$ & $\begin{array}{c}\mathbf{2 0 1 1} \\
\text { Diff }\end{array}$ & $\begin{array}{c}\mathbf{2 0 1 0} \\
\text { Diff }\end{array}$ \\
\hline 1 & $-0.53 \%$ & $2.97 \%$ & $-2.53 \%$ & $-1.35 \%$ & $-0.05 \%$ & $-1.62 \%$ \\
\hline 2 & $-0.51 \%$ & $1.22 \%$ & $-4.81 \%$ & $-4.69 \%$ & $0.04 \%$ & $0.98 \%$ \\
\hline 3 & $-5.83 \%$ & $-5.90 \%$ & $-3.33 \%$ & $-4.17 \%$ & $0.01 \%$ & $1.23 \%$ \\
\hline 4 & $-2.98 \%$ & $-1.16 \%$ & $-1.39 \%$ & $6.09 \%$ & $-0.04 \%$ & $4.08 \%$ \\
\hline 5 & $1.57 \%$ & $0.54 \%$ & $10.40 \%$ & $5.94 \%$ & $0.03 \%$ & $-1.09 \%$ \\
\hline 6 & $5.73 \%$ & $1.84 \%$ & $4.36 \%$ & $0.76 \%$ & $-0.04 \%$ & $-3.71 \%$ \\
\hline 7 & $0.92 \%$ & $-1.03 \%$ & $1.59 \%$ & $0.73 \%$ & $-0.05 \%$ & $1.11 \%$ \\
\hline 8 & $3.37 \%$ & $0.46 \%$ & $-3.37 \%$ & $0.36 \%$ & $0.08 \%$ & $0.68 \%$ \\
\hline 9 & $-1.74 \%$ & $1.06 \%$ & $-0.93 \%$ & $-3.67 \%$ & $0.02 \%$ & $-1.66 \%$ \\
\hline
\end{tabular}

Sources: Proceed by author

TABLE IV RESULT ANALYSIS BENFORD NUMBER PT BANK BRI TBK FOR THE YEAR 2010-2015

\begin{tabular}{|c|c|c|c|c|c|c|}
\hline No. & $\begin{array}{c}\mathbf{2 0 1 5} \\
\text { Diff }\end{array}$ & $\begin{array}{c}\mathbf{2 0 1 4} \\
\text { Diff }\end{array}$ & $\begin{array}{c}\mathbf{2 0 1 3} \\
\text { Diff }\end{array}$ & $\begin{array}{c}\mathbf{2 0 1 2} \\
\text { Diff }\end{array}$ & $\begin{array}{c}\mathbf{2 0 1 1} \\
\text { Diff }\end{array}$ & $\begin{array}{c}\mathbf{2 0 1 0} \\
\text { Diff }\end{array}$ \\
\hline 1 & $-1.58 \%$ & $1.92 \%$ & $-3.58 \%$ & $-2.40 \%$ & $-2.67 \%$ & $-2.67 \%$ \\
\hline 2 & $-0.47 \%$ & $1.26 \%$ & $-4.76 \%$ & $-4.65 \%$ & $1.02 \%$ & $1.02 \%$ \\
\hline 3 & $-5.83 \%$ & $-5.89 \%$ & $-3.32 \%$ & $-4.16 \%$ & $1.23 \%$ & $1.23 \%$ \\
\hline 4 & $-3.02 \%$ & $-1.20 \%$ & $-1.43 \%$ & $6.05 \%$ & $4.03 \%$ & $4.03 \%$ \\
\hline 5 & $1.61 \%$ & $0.57 \%$ & $10.43 \%$ & $5.97 \%$ & $-1.06 \%$ & $-1.06 \%$ \\
\hline 6 & $5.69 \%$ & $1.80 \%$ & $4.31 \%$ & $0.71 \%$ & $-3.75 \%$ & $-3.75 \%$ \\
\hline 8 & $0.57 \%$ & $-1.38 \%$ & $1.24 \%$ & $0.38 \%$ & $0.76 \%$ & $0.76 \%$ \\
\hline 9 & $-1.72 \%$ & $1.08 \%$ & $-0.91 \%$ & $-3.65 \%$ & $-1.63 \%$ & $-1.63 \%$ \\
\hline
\end{tabular}


Of results [Table 2, Table 3, Table 4], By Financial statement PT Bank BRI Tbk 2015, 2014, 2013 and 2012 for the digits 3, 4, 5, and 6 which exceeds the upper limit and lower limit of $5 \%$. As for the rate of appearance of the first digit of the number and other years following the model numbers, Fibonacci and Lucas Benford. According to the author of the results of this analysis, it has been demonstrated that it is indeed a level of truth of a financial report that, with the level of occurrence number that should follow the flow rate of the appearance of the numbers on the analysis model of the first digit on Lucas, fibonacci and benford. Thereby, a true financial reports, without a process engineering numbers according to authors should follow the numeric level of frequencies on the formula of lucas, fibonacci and benford.

\section{CONCLUSION}

For this study do tests with model Lucas numbers, fibonacci numbers and benford to detect the frequency numbers that appear in the financial statements of PT Bank BRI Tbk for years ending in 2010-2015. From the results of research that has been done, you can conclude that the rate of occurrence of the figures in the financial statements of PT Bank BRI Tbk years analyzed 2010-2015, the frequency rate of the appearance of the number following the model of the frequency of Lucas, fibonacci and Benford. But from the results of the analysis as a whole there are several numbers that year in analysis, the number of occurrences of the number levels exceed the upper limit and lower limit which has been specified in the author's 5\%. Thus it is necessary to observe the follow-up digit year that exceed the threshold and the lower limit. The author argues that the presence of Lucas, fibonacci and benford's law shows benefits in the context of "accounting, finance and audit", which in a sense there is less difference than the application instance or an earlier study, the author also considers that the results of this research can be set as the next step. The authors of this study's results argue is something valuable especially related to advances in methods of investigation, associated psychological barriers of the financial statements of the company for the next time.

\section{REFERENCES}

[1] Nigrini, M.J., (1992), "The detection of income tax evasion through an analysis of digital distributions", Ph. D. Dissertation, University of Cincinnaty.

[2] Nigrini, M. J., (1996). A Taxepayer compliance application of Benford's Law. The journal of American Taxation Association, 18 ( Spring), pp. 72-91.

[3] Nigrini, M. J., (1999). I've got your number. Journal Of Accountancy,187 (5) pp. 79-80.

[4] Quick, R., \& Wolz, M. (2005). Benford's law in German financial statements. Finance India, 19, 1285-1302.
[5] Nigrini, M.J. (2000). Digital Analysis Using Benford's Law. Tests \& Statistics for Auditors. Vancouver, BC: Global Audit Publications.

[6] Carslaw, C. A. P. N. (1988), 'Anomalies in income numbers: Evidence of goal oriented behavior', Accounting Review 63(2), 321-327.

[7] McConville, D. (1995). Benford's law traps check fraud perps. Corporate Cashflow, 16, 12-13.

[8] Skousen, C., Guan, L. \& Wetzel, T., (2004). Anomalies and Unusual Patterns in Reported Earnings : Japanese Managers Round Earnings. Journal of International Financial Managment \& Accounting,15 (3), pp. 212-234.

[9] Nigrini, M. (2005). An assessment of the change in the incidence of earnings management around the Enron-Andersen episode. Review of Accounting \& Finance, 4, 92-110.

[10] Blasi, A. (2010). Certified Fraud Examiner. (in article Cristi Tilden and Troy Jones, in Journal of finance and accountancy, volume 10 June 2012, Access download 13 March 2016 (www.aabri.com).

[11] Bowen, H. (2010). Certified Fraud Examiner. (in aricle Cristi Tilden and Troy Jones, in Journal of finance and accountancy, volume 10 June 2012, Acces donwload 13 March 2016 (www.aabri.com).

[12] Gadawaski, G. (2010). (in aricle Cristi Tilden and Troy Jones,in Journal of finance and accountancy, volume 10 June 2012, Access download 13 March 2016 ( www.aabri.com).

[13] Simmons, M. R., (1995). Recognizing the elements of Fraud, s.l.: CIA CFE.

[14] Wells, J. T., (2002). Occupational Fraud: The Audit as Deterrent. Journal of Accountancy, April.

[15] Durtschi, C., Hillison, W. \& Pacini, C. (2004), 'The effective use of Benford's law to assist in detecting fraud in accounting data', Journal of Forensic Accounting 5(1), 17-34.

[16] Collins, D. W., Bruce, J. w. \& Revisine, L., (2005). The Financial Reporting and Analysis. Third Edition ed. Upper Saddle River: Prentice Hall.

[17] Wang, J., Liao, Y., Tsai, T. \& Hung, G., (2006). Technology based financial frauds in Taiwan: issue and approaches. IEEE Conference on: Systems- Man and Cyberspace Oct, pp. 1120-1124.

[18] Albrecht, W., Albrecht, C. \& Albrecht, C. C., (2008). Current Trends in Fraud and its detection. Informational Security Journal : A Global Perspective, 17 (1), pp. 2-12.

[19] Fewster, R. M., (2009). A simple explanation of Benford's Law. The American Statistician,63(1), pp. 26-32.

[20] Abbasi, A., Albrech, C., Vance, A. \& Hansen, J., (2012). Metafraud: A Meta Learning framework for detection financial fraud. Mis Quarterly,36(4), pp. 1293-1327.

[21] Malcolm W. Browne. (1998)., "Following Benford's Law, or Looking Out for No. 1", By (From The New York Times, Tuesday, August 4, T. P. Hill, ,"The First-Digit Phenomenon" , American Scientist, JulyAugust.

[22] Berber, Bernd and Alexandra Scacco. (2008). "What the Numbers Say: A Digit Based Test for Election Fraud Using New Data from Nigeria," paper presented at the Annual Meeting of the American Political Science Association, Boston Ma., August 28- 31

[23] J. Wodarski, (1971). Fibonacci and lucas number tend to obey benfords law, The fibonacci quarterly, Vol.9, No.1, pp.87-88

[24] B.J.Flehinger,(1966) On the probability that a random integers has initial digit A,'Amer, Math, Monthly. Vol.73, pp. 1056-1061. 